\title{
Demand and supply analysis of labor in the agriculture, mining and industrial sector in Jambi Province, Indonesia
}

\section{Zulfanetti $^{1 *}$; FuadMuchlis²; Rendra² ${ }^{2}$ Eristian Wibisono ${ }^{3}$}

1) Development Economics Departement, Faculty of Economics and Business, Universitas Jambi, Indonesia

2) Agribusiness Departement, Faculty of Agriculture, Universitas Jambi, Indonesia

3) Industry and Trade Office of Jambi Province, Indonesia

*Towhom correspondence should be addressed.Email:zulfa_netti@unja.ac.id

\begin{tabular}{|l|l|l|l|l|}
\hline DOI: & Received: & Revised: & Accepted: & Published: \\
10.22437/ppd.v8i2.9026 & 05.04 .2020 & 31.05 .2020 & 05.06 .2020 & 12.06 .2020 \\
\hline
\end{tabular}

\begin{abstract}
The aim of this study is to analyze: 1) The development of labor demand and supply as well as the factors affecting the agriculture, mining and industry sectors in Jambi Province; (2) The factors that affect labor supply in Jambi Province; (3) The factors affecting labor demand in the agriculture, mining and industry sectors in Jambi Province. This study is used secondary data with multiple linear regression analysis tools. The results showed that the labor force growth rate was 3.13 per cent, the agricultural sector labor demand rate was 2.87 per cent, the mining sector labor demand rate was 16.07 per cent, the industrial sector labor demand rate was 7.78 per cent, the agricultural sector's GRDP growth rate was 14, 96 per cent, mining sector GRDP growth rate 28.04 per cent, agriculture sector GRDP growth rate 5.03 per cent, population growth rate 2.31 per cent, PMW growth rate 16.44 per cent, HDI growth rate 0.20 per cent, growth rate agricultural land area 1.66 per cent, investment growth rate in the agricultural sector 14.14 per cent, investment growth rate in the mining sector 91.94 per cent, investment growth rate in the industrial sector 321.78 per cent and growth rate in the number of industries $2.06 \%$. The factors that influence the supply of labor are the variable population and the Provincial Minimum Wage. The factors that influence the demand for labor in the agricultural sector are GRDP variables in the agricultural sector. Factors affecting the demand for labor in the mining sector are the Provincial Minimum Wage and investment in the mining sector. Factors that influence the demand for labor in the industrial sector are the Provincial Minimum Wage.
\end{abstract}

Keywords: Agriculture, Labor demand, Labor supply, Mining and industry sectors JEL Classification: B21, F66, J23

\section{INTRODUCTION}

Human resources in a country (region) has an important role in supporting economic growth. Through a large number of human resources, productive and efficient 
will be a determining factor for the success of economic growth in the country (region). Empirical studies in many countries show that the increase in national income or Gross National Product (GNP) per capita in many countries is determined by the country's success in developing human resource factors, through increasing productivity and achieving work efficiency (Feriyanto, 2014).

This success was done through increasing the mastery of knowledge, skills and abilities of human resources, especially as a workforce. Because it needs to be realized that an increase in the number of human resources that are too fast that is not supported by sufficient skills and knowledge will be a limiting factor for economic growth in the country (region). Therefore, to be able to optimally utilize population growth steps can be carried out as follows. First, there must be control over population growth, so that it can be put to good use. Second, there must be a change in viewing the workforce as partners with capital. Third, it must be able to continue to prepare workers who have good skills and knowledge in order to be able to perform optimally in every economic activity of the business so that it can make a maximum contribution to the national economy.

Labor supply as a result of increasing population, so that more people need jobs. The greater the population, the more labor available for the labor force or non-labor force so that the supply of labor will also be even greater. The larger population will cause greater labor. Thus the greater the number of people looking for work or unemployment (Sukirno, 2004). The population is very influential on the Labor Offer, where if the larger population will increase the number of the workforce so that the number of people looking for workers increases. This is in accordance with Malthus's theory, where the population increases, will increase the supply of labor (Malthus in Arida, Zakiah \& Julaini, 2015).

According to Afrida (2003) labor supply is a function that describes the relationship between the level of wages and the amount of labor offered. The higher the level of wages, the higher the number of labor supply. Wages are as remuneration that must be paid by a company or agency to employees or laborers. The wage level will affect the demand or supply of labor. The government has made regulations on wages (minimum wages) for employees or laborers to meet the minimum living needs. The addition of labor wages will increase the number of people offering to work in the agricultural sector. This indicates that if wages increase will attract workers to become workers in the business (Arida, Zakiah, \& Julaini, 2015).

That minimum wages actually work for those targeted: formal full-time workers earning less than an amount considered necessary to fulfill basic needs (Hohberg \& Lay, 2015). The effects of changes in minimum wage on employment using total paid employment is likely to be underestimated because it includes paid employment that earns a wage below the minimum wage level. In practice, standard theory and literature assumed that the minimum wage compliance is always high. This is not the case in Indonesia where the compliance is relatively low, given the lack of enforcement and the greater proportion of workers in the uncovered sector (Pratomo, 2011).

The area of agricultural land will affect the size of the demand for labor in the production process. The greater the area of agricultural land the greater the amount of labor needed in the production process. Conversely the smaller the agricultural land the less the amount of labor that can be accommodated by agricultural businesses. The more extensive agricultural land the more labor is used, and also the land is one of the most important factors in the production process, where the more extensive the agricultural 
land will increase production. If production increases require people/workers to manage it so that it will cause labor demand ( Arida, Zakiah, \& Julaini, 2015).

The structure of the farm and its production characteristics, in particular its size, specialisation, and productivity, are important determinants of the demand for on-farm labor. Moreover, farm specialisation is not the same across farms, but it is often related to the structure of the farm organisation. The type of structure, whether it is a family farm, a producer cooperative, or a corporate farm, influences the demand for on-farm labor. For example, family farms tend to specialise in labor-intensive activities in comparison to corporate farms, which instead, due to their superior access to land, finance, physical and social capital, focus more on capital intensive production (Tocco, Davidova, \& Bailey, 2012).

In order to highlight the structural impediments and constraints which hinder an efficient allocation of labor and which may affect the structure of the rural economy and the agricultural sector, it is necessary to look at the supply and demand side limitations that characterise rural labor markets. The distinction between supply and demand side is not completely clear-cut but is often blurred, as some problems arise on both sides, as in the case of imperfect information. By the same token, many aspects are interconnected so that some supply-side limitations have implications on the demand for labor, as it is the case for low levels of human capital and limited access to land and capital Tocco, Davidova, \& Bailey, 2012).

One of the efforts that can be carried out to achieve good economic growth is through investment or investment. Investment is the key to achieving economic growth that reflects the increase in the rate of economic growth and people's income. The greater the investment of a country/region and the greater the level of economic growth that can be achieved. The statement indicates the greater investment owned by the business owner, the greater the business can be run, so it requires a large workforce to manage the business (Arida, Zakiah, \& Julaini, 2015).

The expansion of employment opportunities is an effort to develop sectors that are able to absorb the existing workforce in Jambi Province. Efforts to absorb laborcan not be separated from the factors that influence it, such as the development of the population and workforce, economic growth, the level of labor productivity and policies regarding employment itself. This will only have bad consequences if, companies in the agricultural sector and the government lack of attention in addressing this problem because it will cause unemployment in a certain time (Simanjuntak, Yulmardi \& Bhakti, 2018).

This is also in line with Adam Smith's classic theory. This theory regards humans as the main production factors that determine the prosperity of nations. In this case, the classical theory of Adam Smith also saw that the effective allocation of human resources was the beginner of economic growth. The classics believe that an economy based on the strength of the market mechanism will always lead to equilibrium. In a position of balance all resources, including labor, will be used in full (full-employed). Thus, under a system based on the market mechanism, there is no unemployment. If no one works, rather than earning no income at all, they are willing to work at a lower wage. Willingness to work with lower wage rates will attract companies to hire more of them (Sayifullah \& Emmalian, 2018)

As explained in the theory of production according (Sukirno, 2015) that the level of production of goods and services depends on the amount of capital, labor, natural 
wealth, and the level of technology used. This result is in accordance with book theory (Sukirno, 2000), namely an increase in investment increases the demand for labor and national income. Then the agregat demand brings a change in the production capacity of an economy which is then followed by an increase in the need for labor for the production process, thus increasing employment. Investment as expenditure or expenditure of companies to buy production goods, to increase the ability to produce goods and services that come from domestic and foreign investment. The increase in investment will encourage an increase in production volume which in turn will increase productive employment opportunities so that it will increase income per capita (Sulaksono, 2015).

Investments in mining companies aiming to acquire land, buildings or plant expansion, raw materials, machinery and equipment, water, electricity and supply of supporting industries, research and development, pay employees directly or indirectly. Investment elements include exploration costs (drilling, mapping and sampling), additional costs of immovable property, mine development costs, equipment and factory costs, working capital, expansion costs and Environmental Impact Assessment legality costs. This investment increases the income of the mining sector in Indonesia and creates new jobs (Sulaksono, 2015). Investment is a major component in moving the wheels of a country's economy. In theory, an increase in investment will encourage rade volumes and production volumes which in turn will expand productive employment opportunities and will mean increasing per capita income while increasing community welfare (Sulaksono, 2015).

Mining tends to pay well and tends to provide stable employment (Brandon, 2012). Even more dramatic increases in productivity have been achieved in coal with the introduction of large-scale new technology, leading to a dramatic drop in employment (Dansereau, 2007). That mining has a relatively strong positive impact on non-mining employment, but the impact appears to be limited mainly to the private servicesaggregate. In the long run, technological progress will continue to reduce the amount of workers required to operate a mine, and this suggests over time diminishing spillover effects on the local economies (Moritz, Ejdemo, Söderholm, \& Wårell, 2017).

The population of Jambi Province in 2015 is known as much 3,402,052 inhabitants. With a population density of 67.82 people / $\mathrm{km} 2$. With a workforce of $1,620,752$ people consisting of 1,550,403 people working and looking for work/unemployment 70,349 inhabitants. While not the labor force as many as 829,712 people. In addition to increasing the existing human resources, there is also an indication of a shift in the structure of the economy, which is marked by a shift in the number of workers working in the primary sector starting to move to the secondary sector. Seeing the pattern of economic structure shifting and the workforce needs that occur, the thing that needs to be prepared is to improve the quality of human resources in the Jambi Province community (Junaidi, Zulfanetti \& Hardiani, 2014).

Based on the types of the main employment in 2010-2013 in the agriculture, mining and quarrying sectors, as well as the manufacturing industry, the number of population aged 15 years and over has fluctuated each year. Where the highest agricultural sector in 2011 was 851,138 people and the lowest in 2010 was 670,841 people with an average population of 784,501. While in the mining and quarrying sector the highest in 2012 was 27,836 people and the lowest in 2011 was 14,004 people with an average population of 21,987 . In addition, the highest manufacturing sector in 2013 was 52,460 people and the 
lowest in 2010 was 34,821 people with an average population of 42,857.

GDRP Based on the Applicable Price of Jambi Province in 2016 reached Rp 171.71 trillion or $1.36 \%$ of the 2016 national GDP (Rp 12,658.16 trillion). The economic structure of Jambi Province in 2016 was still dominated by agriculture, forestry and fisheries (29.79\%), mining and quarrying (16.59\%), wholesale trade, Retail and Car and Motorcycle Repair (12.15\%), and Processing Industry (10.47\%) (BPS, 2016).

These four economic sectors contributed $69.01 \%$ of the total GDRP of Jambi Province. Plantation commodities (oil palm, rubber) play an important role in encouraging Jambi economic growth (Hardiwan, Amir, Junaidi \& Delis, 2019) especially in the agriculture and processing industries and indirect impacts on trade and service activities.

The problems to be analyzed in this study are:(1) how the development of labor demand and supply as well as the factors affecting the agriculture, mining and industry sectors in Jambi Province; (2) factors affecting labor supply in Jambi Province and (3) factors affecting labor demand in the agriculture, mining and industrial sectors in Jambi Province.

\section{METHODS}

The types of data used in this study are secondary data obtained from the Population Census, the National Socio-Economic Survey (Susenas), the Demographic and Health Survey of Indonesia (SDKI), the National Labor Force Survey (SAKERNAS), and the Jambi Provincial Manpower and Transmigration Office.

To answer the research problem used descriptive quantitative data analysis, which uses multiple linear regression analysis as follows:

$$
\begin{aligned}
& \begin{array}{l}
\text { Model of labor supply in Jambi Province } \\
\text { SL }=\alpha_{0}+\alpha_{1} N P t
\end{array}+\alpha_{2} \mathrm{PMW}_{\mathrm{t}}+\alpha_{3} \mathrm{HDI}_{\mathrm{t}}+\mathrm{e}_{\mathrm{t}} \\
& \begin{array}{ll}
\text { where: } & =\text { Supply of Labor } \\
\mathrm{SL} & =\text { Number of Population (People) } \\
\mathrm{NP}_{\mathrm{t}} & =\text { Provincial Minimum Wage (Rupiah) } \\
\mathrm{PMW}_{\mathrm{t}} & =\text { Human Development Index (Percent) } \\
\mathrm{HDI}_{\mathrm{t}} & =\text { Constant } \\
\alpha_{0} & =\text { Regression Coefficient } \\
\alpha_{1}, \alpha_{2}, \alpha_{3} & =\text { Standard Error } \\
\mathrm{e}_{\mathrm{t}} &
\end{array}
\end{aligned}
$$

\section{Model of labor demand in the agricultural sector}

DLA $=a_{0}+a_{1} A_{L A}+a_{2} I N V A_{t}+a_{3} G R D P A_{t}+e_{t}$

where:

$$
\begin{array}{ll}
\text { DLA } & =\text { Demand for Labor in the Agricultural Sector } \\
\text { ALA }_{t} & =\text { Agricultural Land Area (Ha) } \\
\text { INVA }_{t} & =\text { Investment in the Agricultural Sector (Rupiah) } \\
\text { GRDPA }_{t} & =\text { Gross Regional Domestic Product in the Agriculture Sector (Rupiah) } \\
a_{0} & =\text { Constant } \\
a_{1}, a_{2}, a_{3} & =\text { Regression Coefficient } \\
e_{t} & =\text { Standard Error }
\end{array}
$$




\section{Model of labor demand for in the mining sector}

$\mathrm{DLM}=\mathrm{b}_{0}+\mathrm{b}_{1} \mathrm{GRDPM}_{\mathrm{t}}+\mathrm{b}_{2} \mathrm{PMW}_{\mathrm{t}}+\mathrm{b}_{3} \mathrm{INVM}_{\mathrm{t}}+\mathrm{e}_{\mathrm{t}}$

where:

DLM = Demand for Labor in the Mining Sector

GRDPM $_{\mathrm{t}}=$ Gross Regional Domestic Product in the Mining Sector (Rupiah)

$\mathrm{PMW}_{\mathrm{t}} \quad=$ Provincial Minimum Wage (Rupih)

INVM $_{\mathrm{t}} \quad=$ Investment in the Mining Sector (Rupiah)

$\mathrm{b}_{0} \quad=$ Constant

$b_{1}, b_{2}, b_{3}=$ Regression Coefficient

$\mathrm{e}_{\mathrm{t}} \quad=$ Standard Error

Model of labor demand for industrial sector

LOG (DLI) $=c_{0}+c_{1}$ LOG $(\text { GRDPI })_{t}+c_{2}$ LOG $(\text { PMW })_{t}+c_{3}$ LOG $(\text { INVI })_{t}+$ $\mathrm{c}_{4} \mathrm{LOG}(\mathrm{NI})_{\mathrm{t}}+\mathrm{e}_{\mathrm{t}}$

where:

DLI $=$ Demand for Labor in the Industrial Sector

GRDPI $_{t}=$ Gross Regional Domestic Product in the Industrial Sector (Rupiah)

$\mathrm{PMW}_{\mathrm{t}} \quad=$ Provincial Minimum Wage (Rupiah)

INVI $_{\mathrm{t}} \quad=$ Investment in Industrial Sector (Rupiah)

$\mathrm{NI}_{\mathrm{t}} \quad=$ Number of Industries (Units)

$\mathrm{c}_{0} \quad=$ Constant

$\mathrm{c}_{1}, \mathrm{c}_{2}, \mathrm{c}_{3}=$ Regression Coefficient

$\mathrm{e}_{\mathrm{t}} \quad=$ Standard Error

\section{RESULTS AND DISCUSSION}

Analysis of developing labor demand and supply as well as factors affecting the agriculture, mining and industry sectors in Jambi Province. Development analysis is used to find out the trends in the development of labor demand and supply in Jambi Province and the influencing factors.

Table 1.Development of labor supply in Jambi Province in 2000-2016

\begin{tabular}{ccrrrrr}
\hline \multirow{2}{*}{ Years } & \multicolumn{2}{c}{ Working } & \multicolumn{2}{c}{ Job seeker } & \multicolumn{2}{c}{ Labor force } \\
\cline { 2 - 7 } & Nominal & \multicolumn{1}{c}{$\%$} & Nominal & \% & Nominal & \% \\
\hline 2000 & $1,004,844$ & - & 38,400 & - & $1,043,244$ & - \\
2001 & $1,013,666$ & 0.88 & 60,240 & 56.88 & $1,073,906$ & 2.94 \\
2002 & $1,094,331$ & 7.96 & 67,092 & 11.37 & $1,161,423$ & 8.15 \\
2003 & $1,101,833$ & 0.69 & 76,659 & 14.26 & $1,178,492$ & 1.47 \\
2004 & $1,137,460$ & 3.23 & 73,108 & -4.63 & $1,210,568$ & 2.72 \\
2005 & $1,113,150$ & -2.14 & 133,964 & 83.24 & $1,247,114$ & 3.02 \\
2006 & $1,103,386$ & -0.88 & 78,264 & -41.58 & $1,181,650$ & -5.25 \\
2007 & $1,146,851$ & 3.94 & 76,090 & -2.78 & $1,222,941$ & 3.49 \\
2008 & $1,224,483$ & 6.77 & 66,371 & -12.77 & $1,290,854$ & 5.55 \\
2009 & $1,260,592$ & 2.95 & 73,904 & 11.35 & $1,334,496$ & 3.38 \\
2010 & $1,360,022$ & 7.89 & 72,792 & -1.50 & $1,432,814$ & 7.37 \\
2011 & $1,434,998$ & 5.51 & 60,169 & -17.34 & $1,495,167$ & 4.35 \\
2012 & $1,423,624$ & -0.79 & 42,296 & -29.70 & $1,465,920$ & -1.96 \\
2013 & $1,382,471$ & -2.89 & 70,361 & 66.35 & $1,452,832$ & -0.89 \\
2014 & $1,491,038$ & 7.85 & 79,784 & 13.39 & $1,570,822$ & 8.12 \\
2015 & $1,550,403$ & 3.98 & 70,349 & -11.83 & $1,620,752$ & 3.18 \\
2016 & $1,624,522$ & 4.78 & 67,671 & -3.81 & $1,692,193$ & 4.41 \\
\hline Average & $\mathbf{1 , 2 6 2 , 8 0 4}$ & $\mathbf{3 . 1 1}$ & $\mathbf{7 1 , 0 3 0}$ & $\mathbf{8 . 1 8}$ & $\mathbf{1 , 3 3 3 , 8 3 6}$ & $\mathbf{3 . 1 3}$ \\
\hline
\end{tabular}

Source: BPS-Statistics of Jambi Province (2000-2016) 
Based on Table 1 it show that the average labor force in Jambi Province for the period of 2000-2016 is only 1,262,804 people per year. The average person looking for work is only 71,030 people per year. While the number of employed people reaches $1,262,804$ people per year. If seen from the annual growth rate, in 2002 the number of people employed reached 7.96 per cent. In 2013 it decreased by -2.80 per cent. In 2005 the number of people looking for work in Jambi Province reached 83.24 per cent. While in 2016 it decreased by -41.58 per cent. The total workforce in Jambi Province in 2013 reached 8.15 per cent. This growth slowed in 2006, reaching only -5.25 per cent.

Table 2. Development of labor demand in Jambi Province in 2000-2016

\begin{tabular}{ccrrrrr}
\hline \multirow{2}{*}{ Years } & \multicolumn{1}{c}{ DLA } & \multicolumn{1}{c}{ DLM } & \multicolumn{1}{c}{ DLI } & \\
\cline { 2 - 7 } & Nominal & \multicolumn{1}{c}{$\%$} & Nominal & \% & Nominal & \multicolumn{1}{c}{} \\
\hline 2000 & 531,754 & - & 5,741 & - & 28,846 & - \\
2001 & 579,303 & 8.94 & 7,028 & 22.42 & 36,406 & 26.21 \\
2002 & 631,104 & 8.94 & 8,604 & 22.42 & 45,947 & 26.21 \\
2003 & 687,536 & 8.94 & 10,534 & 22.43 & 57,989 & 26.21 \\
2004 & 743,971 & 8.21 & 13,888 & 31.84 & 48,017 & -17.20 \\
2005 & 631,399 & -15.13 & 11,737 & -15.49 & 76,374 & 59.06 \\
2006 & 683,224 & 8.21 & 9,587 & -18.32 & 60,514 & -20.77 \\
2007 & 662,143 & -3.09 & 9,257 & -3.44 & 48,132 & -20.46 \\
2008 & 706,903 & 6.76 & 12,835 & 38.65 & 46,462 & -3.47 \\
2009 & 729,340 & 3.17 & 21,024 & 63.80 & 41,675 & -10.30 \\
2010 & 810,866 & 11.18 & 24,769 & 17.81 & 50,017 & 20.02 \\
2011 & 770,848 & -4.94 & 21,517 & -13.13 & 48,786 & -2.46 \\
2012 & 783,501 & 1.64 & 27,836 & 29.37 & 47,303 & -3.04 \\
2013 & 723,973 & -7.60 & 26,433 & -5.04 & 52,552 & 11.10 \\
2014 & 736,204 & 1.69 & 33,853 & 28.07 & 52,473 & -0.15 \\
2015 & 819,545 & 11.32 & 26,732 & -21.04 & 61,998 & 18.15 \\
2016 & 800,719 & -2.30 & 41,920 & 56.82 & 71,547 & 15.40 \\
\hline Average & $\mathbf{7 0 7 , 7 8 4}$ & $\mathbf{2 . 8 7}$ & $\mathbf{1 8 , 4 2 9}$ & $\mathbf{1 6 . 0 7}$ & $\mathbf{5 1 , 4 7 3}$ & $\mathbf{7 . 7 8}$ \\
\hline
\end{tabular}

Source: BPS-Statistics of Jambi Province (2000-2016)

Based on Table 2 it show that the average labor demand in Jambi Province for the period 2000-2016 is still dominated by the agricultural sector at 707,784 people. While the least demand was in the mining sector at 18,429 people. If seen from the rate of growth, labor demand in the mining and industrial agriculture sector in 2000-2004 was relatively stable. But in 2005 the demand for labor in the agricultural sector decreased by -15.13 per cent. In the mining sector, the increase in 2009 was quite high at 63.80 per cent and declined again in 2015 of -21.04 per cent. Whereas the industrial sector in 2005 increased so sharply that it amounted to 59.06 per cent.

Based on Table 3 it show that the average rate of economic growth in the mining sector in 2000-2016 was 28.04 per cent. The average rate of economic growth in the agricultural sector is 14.96 per cent. While the average rate of economic growth in the industrial sector was 5.03 per cent. The rate of economic growth in Jambi Province in 2001 reached 387.27 per cent, far higher than the year before and after. However, in 2006 the economic growth rate in the mining sector decreased by -7.29 per cent. The rate of economic growth in the agricultural sector in 2001 reached 238.56 per cent. Whereas in 2016 it decreased by -84.98 per cent. The rate of economic growth in the industrial sector in Jambi Province fluctuates. In 2002 it was the highest rate of economic growth, reaching 
10.09 per cent. In 2013 it reached 8.17 per cent and again declined until 2016 which reached 2.29 per cent.

Table 3. Gross Regional Domestic Product (GRDP) of the agriculture, mining and industry sectors based on constant prices in 2010, period 2000-2016 (million rupiahs)

\begin{tabular}{crrrrrr}
\hline \multirow{2}{*}{ Year } & \multicolumn{1}{c}{ GRDPA } & \multicolumn{3}{c}{ GRDPM } & \multicolumn{3}{c}{ GRDPI } & \\
\cline { 2 - 7 } 2000 & \multicolumn{1}{c}{ Nominal } & \multicolumn{1}{c}{ \% } & Nominal & \% & \multicolumn{1}{c}{ Nominal } & \multicolumn{1}{c}{ - } \\
2001 & $14,337,801.815 .04$ & 238.56 & $17,477,662.43$ & - & $6,530,991.43$ & - \\
2002 & $15,032,448.73$ & 4.85 & $17,167,144.92$ & -1.52 & $7,450,737.01$ & 10.09 \\
2003 & $15,566,925.01$ & 3.56 & $17,650,400.86$ & 2.82 & $7,626,469.11$ & 2.36 \\
2004 & $16,358,106.76$ & 5.08 & $17,765,323.71$ & 0.65 & $7,897,340.12$ & 3.55 \\
2005 & $17,111,658.95$ & 4.61 & $17,950,327.57$ & 1.04 & $8,205,368.88$ & 3.90 \\
2006 & $19,051,414.29$ & 11.34 & $16,642,442.98$ & -7.29 & $8,569,962.08$ & 4.44 \\
2007 & $19,921,629.76$ & 4.57 & $18,240,896.53$ & 9.60 & $9,036,653.26$ & 5.45 \\
2008 & $21,060,812.35$ & 5.72 & $20,922,122.25$ & 14.70 & $9,545,850.75$ & 5.63 \\
2009 & $22,462,616.11$ & 6.66 & $21,191,451.56$ & 1.29 & $9,912,755.86$ & 3.84 \\
2010 & $23,627,241.97$ & 5.18 & $24,255,278.20$ & 14.46 & $10,357,580.68$ & 4.49 \\
2011 & $24,744,879.37$ & 4.73 & $27,265,306.60$ & 12.41 & $11,217,086.31$ & 8.30 \\
2012 & $26,429,045.13$ & 6.81 & $28,595,774.90$ & 4.88 & $12,023,508.82$ & 7.19 \\
2013 & $28,070,963.00$ & 6.21 & $29,692,334.90$ & 3.83 & $13,005,650.26$ & 8.17 \\
2014 & $31,145,428.62$ & 10.95 & $30,951,985.90$ & 4.24 & $13,630,734.50$ & 4.81 \\
2015 & $32,846,193.30$ & 5.46 & $30,879,897.00$ & -0.23 & $13,948,630.01$ & 2.33 \\
2016 & $4,933,688.60$ & -84.98 & $31,016,887.70$ & 0.44 & $14,267,736.88$ & 2.29 \\
\hline Average & $\mathbf{1 9 , 8 1 9 , 7 1 5 . 8 1}$ & $\mathbf{1 4 . 9 6}$ & $\mathbf{2 1 , 8 3 5 , 1 7 2 . 9 6}$ & $\mathbf{2 8 . 0 4}$ & $\mathbf{9 , 9 9 9 , 6 9 4 . 9 3}$ & $\mathbf{5 . 0 3}$ \\
\hline
\end{tabular}

Source: BPS-Statistics of Jambi Province (2000-2016)

Based on Table 4 shows that the factors affecting labor supply in Jambi Province during the period 2000-2016 are the population, PMW and HDI. The average population in Jambi Province is 2,895,896 people with an average growth rate of 2.31 per cent. The average PMW in Jambi Province is 838,609 rupiah with a PMW growth rate of 16.44 per cent. While the average HDI in Jambi Province was 69.16 per cent with an HDI growth rate of 0.20 per cent.

Table 4. Factors affecting labor supply and demand in 2000-2016

\begin{tabular}{lrr}
\hline \multicolumn{1}{c}{ Labor Factor } & Average & Average (\%) \\
\hline Supply & & \\
Total Population (People) & $2,895,896$ & 2.31 \\
PMW (Rupiah) & 838,609 & 16.44 \\
HDI (Percent) & 69.16 & 0.20 \\
Agricultural Sector Demand & & \\
Agricultural Land Area (Ha) & $1,417,359$ & 1.66 \\
Investment (Rupiah) & 167,852 & 14.14 \\
GDRP (Million Rupiah) & $19,819,716$ & 14.96 \\
Demand for the Mining Sector & & \\
GDRP (Million Rupiah) & $21,835,173$ & 28.04 \\
Investment (Rupiah) & 9,837 & 91.94 \\
Demand for the Industrial Sector & & \\
GDRP (Million Rupiah) & $9,999,695$ & 5.03 \\
Investment (Rupiah) & $4,076,375,044$ & 321.78 \\
Number of Industries (Units) & 23,150 & 2.06 \\
\hline
\end{tabular}

Source: Investment and One Stop Integrated Services Office, Jambi Province (2000-2016) 
The demand for labor in the agricultural sector in Jambi Province is affected by land area, investment and GRDP. The average area of agricultural land in Jambi Province is $1,417,359$ hectares with a growth rate of 1.66 per cent. The average investment value is 167,852 with a growth rate of 14.14 per cent. While the average GDP of 19,819,716 rupiahs with an economic growth rate of 14.96 per cent.

The demand for labor in the mining sector in Jambi Province is affected by GRDP and investment. The average GRDP in the mining sector is $21,835,173$ rupiah with an economic growth rate of per cent. While the average investment value was 9,837 rupiahs with a growth rate of 91.94 per cent.

The demand for labor in the industrial sector in Jambi Province is influenced by the GRDP, investment and the number of industries. The average GRDP of the industrial sector was 9,999,695 rupiah with an economic growth rate of 5.03 per cent. The average investment value of 4,076,375,044 rupiahs with an economic growth rate of 321.78 per cent.while the average number of industries in Jambi province reached 23,150 units with a growth rate of 2.06 per cent.

\section{Analysis of factors affecting labor supply in Jambi Province}

Table 5 presents results of factors affecting labor supply in Jambi Province. The variable population has a positive effect on labor supply (probability $=0.0814$ ). The results of this study are in accordance with the theory that the greater the number of population, the more labor available for both the labor force and non-labor force so that the number of labor supply will also be greater (Triani \& Andrisani, 2019). It can be concluded that the population will have a positive and significant influence on labor supply in Indonesia. This means that each additional population will increase the number of labor supply in Indonesia. Influence (Triani \& Andrisani, 2019). The results of this study are in research conducted by Sofyan, Iskandar \& Izzati (2015), one of the main problems in employment is lowlabor productivity. The problem of the quality of human resources is also closely related to the problem of population. Very high population growth also affects the number of the labor force who will participate in the development or it can be said the number of labor force entering the labor market will increase.

Table 5. Estimated results of factors affecting labor supply

\begin{tabular}{lrlrc}
\hline Variable & Coefficient & Std. Error & t-Statistic & \multicolumn{1}{c}{ Prob. } \\
\hline C & 477881.4 & 667993.7 & 0.715398 & 0.4870 \\
NP & 0.271652 & 0.143791 & 1.889207 & 0.0814 \\
PMW & 0.174983 & 0.096511 & 1.813093 & 0.0930 \\
HDI & -1119.999 & 5909.604 & -0.189522 & 0.8526 \\
\hline R-squared & 0.964636 & Mean dependent var & 1333835 \\
Adjusted R-squared & 0.956475 & S.D. dependent var & 193684.8 \\
S.E. of regression & 40407.70 & Akaike info criterion & 24.25375 \\
Sum squared resid & $2.12 \mathrm{E}+10$ & Schwarz criterion & 24.44980 \\
Log likelihood & -202.1569 & Hannan-Quinn criter. & 24.27324 \\
F-statistic & 118.2020 & Durbin-Watson stat & 1.446781 \\
Prob(F-statistic) & 0.000000 & & \\
\hline
\end{tabular}

The Provincial Minimum Wage variable has a positive effect on labor supply (probability $=0.0930$ ).If wages rise, the amount of labor offered will increase and vice versa. The minimum wage has a direct role in the work time offered. In most people, high wages become a stimulus or motivation to work, in general wages have a positive 
correlation with the work time offered (Yuliani, 2013). In its development, the demand and supply of labor in the agricultural sector are influenced by the labor market. The demand for and supply of labor in the agricultural sector is affected by changes in wages received (Conradie, 2004). High-wage employment will cause a high number of laborsupply too, on the other hand, low-wage jobs will cause low labor supply too. In other words, the wages offered by companies are positively related to labor supply. However, based on research on the existence of wage rigidity, or better known as wage rigidity, is the failure of wages to make adjustments to the supply of labor equal to labor demand. This failure to indicate wage rates often causes unemployment problems (Mankiw, 2003).The regression results show that the Human Development Index has no significant effect on labor supply.

\section{Analysis of the factors that affect labor demand in the agriculture, mining and industrial sectors in Jambi Province}

Table 6 presents results of factors affecting the demand for workers in the agricultural, mining and industrial sectors. The area of agricultural land and investment in agriculture have no significant effect on the demand for labor in the agricultural sector.The GRDP variable in the agricultural sector has a positive effect on labor demand in the agricultural sector (probability $=0.0024$ ).

This is in line with research conducted byTambunan (2011) states that besides the demand (consumption) side, in terms of supply, population growth also requires growth in employment opportunities (sources of income). Economic growth without being accompanied by additional employment opportunities will lead to inequality in the distribution of additional income (ceteris paribus), which in turn will create a condition of economic growth with increased poverty. Meeting the consumption needs and employment opportunities itself can only be achieved by a continuous increase in aggregate output (goods and services) or GRDP. In the understanding of macroeconomics, economic growth is the addition of GRDP.

Table 6. Estimated results of factors affecting the demand for workers in the agricultural, mining and industrial sectors

\begin{tabular}{llrlll}
\hline \multicolumn{1}{c}{ Sector } & Variable & Coefficient & Prob & R-squared & \multicolumn{1}{c}{ F-statistic } \\
\hline Agricultural & ALA & 0.064940 & 0.5902 & & \\
Sector & INVA & 0.016498 & 0.8910 & \multirow{2}{*}{0.722723} & $\mathrm{~F}=11.29482$ \\
& GRDPA & 0.008629 & 0.0024 & & Prob=0.000634 \\
& Constant & 426712.7 & 0.0186 & & \\
\hline Mining & GRDPM & 0.000186 & 0.5070 & & $\mathrm{~F}=43.84679$ \\
Sector & PMW & 0.018570 & 0.0005 & \multirow{2}{*}{0.910060} & Prob $=0.000000$ \\
& INVM & -0.100273 & 0.0976 & & \\
& Constant & -208.4319 & 0.9532 & & \\
\hline Industrial & LOG (GRDPI) & -2.406900 & 0.1181 & & $\mathrm{~F}=3.312362$ \\
Sector & LOG (PMW) & 1.366699 & 0.0583 & 0.524742 & Prob $=0.047804$ \\
& LOG (INVI) & 0.030216 & 0.4984 & & \\
& LOG (NI) & -2.208489 & 0.3251 & & \\
& Constant & 52.80586 & 0.0851 & & \\
\hline
\end{tabular}

The mining sector regression results show that the GRDP of the mining sector has no significant effect on the demand for mining sector workers. The Provincial Minimum Wage variable has a positive effect on the demand for mining workers 
(probability=0.0005). This means that wage increases will increase the use of labor. Jobs in the mining sector include management and operators who have high investment and work risks, so high risk high income applies. For management the success of exploration will reduce investment risk, failure of exploration is a high risk for investment. For labor operators also have a high enough risk, so that salaries/wages are relatively high compared to other sectors.This is not in line with research conducted by (Fikri, 2018) which states that the wage variable has no significant effect on employment in the Indonesian mining sector. This happens because wage movements do not directly affect the demand and supply of labor in the mining sector. In addition, the mining sector is a sector that absorbs more outsourcing workers so that the majority of the workforce or laborers in mining companies are outsourced labor. In this outsourcing policy the company has the freedom to determine how much wages will be paid to workers, and workers who approve it will get wages in accordance with the contract even though the agreed wages are below the stipulated sectoral minimum wage. This then makes the movement of mining sectoral wages, both when increasing or decreasing, not affect the absorption of labor in this sector because workers are employed according to wages in contract rather than sectoral wages. Another reason that makes wages insignificant to employment is that mining companies are willing to pay workers at any level of wages given the difficulty in getting criteria for mine workers who are willing and able to work in this sector.

The investment variable in the mining sector has a negative effect on the demand for labor in the mining sector (probability=0.0976). This means that the increase in investment has no impact on the addition of workers in the mining sector. It is understood that investment in the mining sector is mostly used for land acquisition, land clearing, purchasing or leasing heavy equipment, making Environmental Impact Assessment, infrastructure and equipment.

The industrial sector regression results show that the GRDP of the industrial sector, investment in industrial sector and number of industrieshave no significant effect on the demand for industrial sector labor. The provincial minimum wage variable has a positive effect on the demand for labor in the industrial sector (probability $=0.0583$ ). This is in line with research conducted by According to Sari's research (2013) analyzing that the factors that determine employment in agriculture, industry and construction in Sumatra Island are the gross regional domestic product (GRDP), provincial minimum wage (PMW), and foreign direct investment (FDI). While the factors that influence employment in the mining sector are GRDP. Whereas the effect on employment in the industrial sector is the minimum wage and the number of industries, other variables such as the real GRDP of the industrial sector does not affect labor absorption.

The regression results show that investment in the industrial sector has no significant influence on the demand for labor in the industrial sector.In this case investment value is still estimated to have a negative effect because many industries use capital-intensive (machinery) and reduce the number of workers because capital-intensive techniques with high technology result in productivity and efficiency being better, with the same large output only with labor that is a little (Ariska, 2018).The regression results show that the number of industries has no significant effect on the demand for labor in the industrial sector. 


\section{CONCLUSIONS AND RECOMMENDATIONS}

\section{Conclusions}

The results from 2000-2016 showed that the average rate of growth of the labor force was 3.13 per cent, the average rate of labor demand for agricultural sector was 2.87 per cent, the average rate of labor demand for mining sector was 16.07 per cent and the average rate of labor demand for industrial sector was 7.78 per cent. While the data variables in the study increased and fluctuated.

The factors that influence the supply of labor are the variable population and the Provincial Minimum Wage. The factors that influence the demand for labor in the agricultural sector are GRDP variables in the agricultural sector. Factors affecting the demand for labor in the mining sector are the Provincial Minimum Wage and investment in the mining sector. Factors that influence the demand for labor in the industrial sector are the Provincial Minimum Wage.

\section{Recommendations}

It is expected that the workforce is able to improve competency, skills and education. It is hoped that the government can provide facilities and infrastructure for infrastructure and education in the field of education and health. Expected to be able to invest in sectors and activities that can absorb a lot of labor, especially those that can increase the creativity of the workforce and increase the added value of the products produced and provide appropriate wages. It is hoped that further research can be carried out regarding labor supply and demand with broader variables and dimensions.

\section{ACKNOWLEDGMENT}

Researchers give thanks to all those who helped in completing this research, in particular: To the Chancellor, Postgraduate Director, Chair of the Master of Population and Labor Studies Study Program (MIKK) and Chairperson of the LPPM University of Jambi for his trust in researchers to carry out this research and funding support. Research contract agreement letter Number: 1813 / UN21.17 / LT / 2018 dated April 23, 2018.

\section{REFERENCES}

Afrida, (2003). Ekonomi Sumberdaya Manusia.Ghalia Indonesia. Jakarta.

Arida, A., Zakiah, \& Julaini. (2015). Analisis Permintaan Dan Penawaran Tenaga Kerja Pada Sektor Pertanian Di Provinsi Aceh. Agrisep, 16(1), 66-78. https://doi.org/10.24815/agrisep.v16i1.3033

Ariska, B. O. (2018). Analisis Permintaan Tenaga Kerja Pada Industri Kecil Dan Menengah Di Kabupaten Gresik. Jurnal Ilmu Ekonomi, 2(1), 83-94.

Badan Pusat Statistik (BPS). (2016). Provinsi Jambi Dalam Angka. Jambi: BPS Provinsi Jambi.

Brandon, B. C. N. (2012). Emerging Workforce Trends in the U.S. Mining Industry. Automated System Alliance Inc, January, 1-38.

Conradie, B. (2004). Centre for Social Science Research Wages and Wage Elasticities for Wine and Table Grapes in South Africa. Center for Social Research, 90, 1-21.

Dansereau, S. (2007). Globalization and mining labor: Wages, skills and mobility. Minerals and Energy - Raw Materials Report, 21(2), 8-22. https://doi.org/10.1080/14041040600977845

Fikri, C.R. (2018). Analisis Pengaruh Produk Domestik Bruto, Ekspor, dan Upah 
Terhadap Penyerapan Tenaga Kerja Sektor Pertambangan Indonesia. Jurnal Ilmiah. Mahasiswa FEB Universitas Brawijaya, Malang, 6(2)

Feriyanto, N. (2014). Ekonomi Sumber Daya Manusia, Dalam Perspektif Indonesia. Yogyakarta: UPP STIM YKPN.

Hardiwan, D., Amir, A., Junaidi, J. \& Delis, A. (2019). The Linkages and Impact of Plantation-Based Sector on Economy and Poverty in Jambi Province, Indonesia: Miyazawa's Input-Output Model. Agricultural and Resource Economics: International Scientific E-Journal, 5(3), 5 - 19

Hohberg, M., \& Lay, J. (2015). The impact of minimum wages on informal and formal labor market outcomes: evidence from Indonesia. IZA Journal of Labor and Development, 4(1), 1-25. https://doi.org/10.1186/s40175-015-0036-4

Junaidi, Zulfanetti, \& Hardiani. (2014). Analisis Kondisi dan Proyeksi Ketenagakerjaan di Provinsi Jambi. Jurnal Perspektif Pembiayaan Dan Pembangunan Daerah, 3(3), 141-150. https://doi.org/10.13140/RG.2.1.2172.9042

Mankiw, N. G.(2003). Teori Makroekonomi. Jakarta: Penerbit Erlangga.

Moritz, T., Ejdemo, T., Söderholm, P., \& Wårell, L. (2017). The local employment impacts of mining: an econometric analysis of job multipliers in northern Sweden. Mineral Economics, 30(1), 53-65. https://doi.org/10.1007/s13563-017-0103-1

Pratomo, D.S. (2011). The effects of changes in minimum wage on employment in Indonesia: Regional panel data analysis. International Research Journal of Finance and Economics, 62, 15-27.

Sari, N.(2013). Faktor-Faktor Yang Memengaruhi Penyerapan Tenaga Kerja Di Pulau Sumatera 2006-2010. Bogor: Institut Pertanian Bogor.

Sayifullah, S., \& Emmalian, E. (2018). Pengaruh Tenaga Kerja Sektor Pertanian Dan Pengeluaran Pemerintah Sektor Pertanian Terhadap Produk Domestik Bruto Sektor Pertanian Di Indonesia. Jurnal Ekonomi-Qu, 8(1), 66-81. https://doi.org/10.35448/jequ.v8i1.4962

Simanjuntak, M., Yulmardi, \& Bhakti, A. (2018). Pengaruh GRDP Sektor Pertanian , Nilai Tukar Petani dan Investasi Sektor Pertanian terhadap Penyerapan Tenaga Kerja Sektor Pertanian Provinsi Jambi. E-Jurnal Ekonomi Sumberdaya Dan Lingkungan, 7(1), 1-12.

Sofyan, Iskandar, E., \& Izzati, Z. (2015). Analisis Kesempatan Kerja Dan Produktivitas Tenaga Kerja Pada Sektor Pertanian Di Provinsi Aceh. Agresip, 16(2), 1-7. https://doi.org/10.24815/agrisep.v16i2.3040

Sukirno, S. (2015).Pengantar Ekonomi Makro. Jakarta: Raja Grafindo Persada.

Sukirno, S. (2000).Teori Mikro Ekonomi. Jakarta: Raja Grafindo Persada.

Sukirno, S. (2004). Ekonomi Pembangunan: Proses, Masalah dan Dasar Kebijakan. Jakarta: Kencana Prenada Media Group.

Sulaksono, A. (2015). Pengaruh Investasi Dan Tenaga Kerja Terhadap PDB Sektor Pertambangan Di Indonesia. Jurnal Ekonomi Bisnis, 20(1), 16-24.

Tocco, B., Davidova, S., \& Bailey, A. (2012). Key Issues in Agricultural Labor Markets: A Review of Major Studies and Project Reports on Agriculture and Rural Labor Markets. Factor Markets, 32(20), 1-38.

Tocco, B., Davidova, S., \& Bailey, A. (2012). Supply and Demand Side Limitations Affecting the Structure of Agriculture and the Rural Economy. Factor Markets, 21, $1-10$.

Tambunan, T. (2011). Perekonomian Indonesia Kajian Teoritis dan Analisis Empiris. 
Jakarta: Ghalia Indonesia.

Triani, M., \& Andrisani, E. (2019). Analisis Pengaruh Jumlah Penduduk Dan Upah Terhadap Penawaran Tenaga Kerja Di Indonesia. Jurnal Geografi, 8(1), 49-54. https://doi.org/10.24036/geografi/vol8-iss1/568

Yuliani. (2013). Faktor-Faktor yang Mempengaruhi Penawaran Tenaga Kerja di Kota Samarinda. Journal of Chemical Information and Modeling, 3(9), 1689-1699. https://doi.org/10.1017/CBO9781107415324.004 article distributed under the terms and conditions of the Creative Commons Attribution (CC BY) license (http://creativecommons.org/licenses/by/4.0/). 